\title{
Free Will Skepticism and Personhood as a Desert Base
}

\section{Introduction}

In contemporary free will theory, a significant number of philosophers are once again taking seriously the possibility that human beings do not have free will, and are therefore not morally responsible for their actions. (Free will is understood here as whatever satisfies the control condition of moral responsibility.) Free will theorists commonly assume that giving up the belief that human beings are morally responsible implies giving up all our beliefs about desert. ${ }^{1}$ But the consequences of giving up the belief that we are morally responsible are not quite this dramatic. Giving up the belief that we are morally responsible undermines many, and perhaps most, of the desert claims we are pretheoretically inclined to accept. But it does not undermine desert claims based on the sheer fact of personhood. Even in the absence of belief in moral responsibility, personhood-based desert claims require us to respect persons and their rights. $^{2}$ So personhood-based desert claims can provide a substantial role for desert in free will skeptics' ethical theories.

This paper has four sections. In the first, I will explain the idea that desert claims can be based on personhood alone by way of a comparison with Saul Smilansky's account of desert. The second and third sections are arguments against claims which imply that skepticism about free will undermines personhood-based desert claims along with action-based desert claims. The second section is an argument against the claim that one's personhood can be a desert base only insofar as one is morally responsible for becoming a person, and the third section is an argument against the claim that personhood implies moral responsibility. In the fourth section, I will use an argument involving a version of Rawls' original position to sketch what justice would be if personhood were the only legitimate desert base. I will argue that even if the belief in moral 
responsibility is given up, and action-based desert claims are therefore rejected, personhoodbased desert claims can be used to reconstruct legitimate analogues of action-based desert claims in some cases.

\section{The Idea of Personhood as a Desert Base, and a Comparison with Smilansky}

To begin, let us consider in more detail why free will theorists often think giving up the belief in moral responsibility implies giving up all our beliefs about desert. Joel Feinberg's idea of desert bases is helpful here (Feinberg, 1963). ${ }^{3}$ A desert base is whatever grounds a desert claim. It is widely agreed that an action can be a desert base only if an agent is morally responsible for that action. For example, an agent can deserve to be blamed for an action only if he is morally responsible for that action. This means that if one rejects the belief that agents are morally responsible, one must also reject the belief that actions are desert bases. But actions are the only kind of desert base typically under consideration in free will theory. This makes it natural for free will theorists to suppose that rejecting moral responsibility implies that there are no legitimate desert bases. This does not follow, however, if actions are not the only kind of desert base.

It is by no means absurd to suppose that actions are the only kind of desert base, since the category of action-based desert claims is very broad. Desert claims about praise, blame, reward, and punishment are all typically based on actions, and desert claims about property are based on actions when construed in Lockean terms (i.e. in terms of the idea that one comes to deserve property when one "mixes one's labor" with objects). Action-based desert claims also include claims that might initially appear to be character-based, because fair-minded ethicists recognize that legitimate desert claims can be based on agents' character-traits only if those agents have acted in such a way as to develop or cultivate those traits. ${ }^{4}$ 
Yet despite the breadth of the category of action-based desert claims, there are desert claims that cannot plausibly be supposed to be based on actions. For example, a person deserves respect, access to her rights, equal treatment before the law, and not to be used as a mere means to others' ends, and she deserves these things not because of facts about her actions, but simply because she is a person. ${ }^{5}$ In other words, these kinds of desert are based not on actions, but on personhood. All action-based desert claims are in a sense based on personhood as well as actions, because only persons could be morally responsible for actions. But some desert claims are based only on the sheer fact of personhood, and these desert claims are not undermined by giving up the belief in moral responsibility.

The approach to action- and personhood-based desert to be taken in this paper can be explained in more detail by contrast with Saul Smilansky's approach. According to Smilansky, all non-trivial desert claims depend on the idea of moral responsibility for actions. He accepts that there is a minimum level of well-being which persons can be said to deserve just because they are persons. Smilansky calls this a "baseline" of well-being. But he argues that we can only explain why people who fall below that baseline deserve special treatment if our explanation is grounded on facts about their actions.

Smilansky illustrates his argument with an example about the residents of a town whose air has been seriously polluted by a chemical factory. He accepts that there is no "responsibilitybase", i.e. no action-base, for the "desert of fresh air". That is, the residents can legitimately claim to deserve fresh air just because they are persons. But Smilansky holds that when the residents fall below the fresh air baseline because of the factory's pollution, the mere fact that they are persons cannot explain why they deserve special treatment (e.g. compensation). To explain why the residents deserve special treatment, we must base our claims on facts about their 
actions: "since the people of the town are not responsible for the pollution (they have done nothing to deserve it), they deserve e.g. compensation" $(1996,159)$. On Smilansky's view, desert claims not based on actions are toothless when it comes to explaining why people who fall below the baseline deserve special treatment, and in this sense, such claims are trivial. ${ }^{6}$ If Smilansky is correct, then the distinction between personhood- and action-based desert claims is not as significant as I have suggested so far in this paper.

Smilansky's baseline metaphor is very useful for thinking about desert, and he is right to hold that we deserve this baseline just because we are persons. But he is mistaken to hold that when someone falls below it, her claim to deserve special treatment must be based on the claim that she did nothing to deserve to fall below it. That she did nothing to deserve to fall below it could only be the correct explanation of why she deserves special treatment for falling below it if it is conceivable that she could do something to deserve to fall below it. To say that something is the case because a condition does not obtain which could not conceivably obtain is to explain nothing. For some desert claims, it is not conceivable that there is anything one could do to deserve to fall below the relevant baseline.

Consider another of Smilansky's own examples of baseline desert: "everyone should be treated as innocent until proven guilty" $(2000,44)$. There is nothing anyone could conceivably do to deserve not to be treated as innocent until proven guilty. Someone who was not treated as innocent until proven guilty could legitimately claim to deserve special treatment. But she could not explain this claim by pointing out that she had not done anything to deserve not to be treated as innocent until proven guilty, because there is nothing anyone could conceivably do to deserve not to be treated as innocent until proven guilty. That explanation would not explain anything. Other desert claims with this structure include the ones mentioned at the outset of this paper, i.e. 
our claims to deserve respect, access to our rights, equal treatment before the law, and not to be used as a mere means to others' ends.

The fact that there is nothing anyone could conceivably do to deserve to fall below the baseline in these cases shows that Smilansky is mistaken to hold that persons' claims to deserve special treatment when they fall below the baseline must be based on their actions. This fact does not imply that these desert claims are personhood-based, only that they are based on some un-chosen attribute of persons. For example, those who reject moral universalism might suppose that someone's claim to deserve to be treated as innocent until proven guilty is based on the fact that he is a member of our state or community. But for those who are antecedently committed to moral universalism, it is plausible to suppose that these desert claims are based on personhood. ${ }^{7}$

Smilansky's fresh air example may seem to support his position, because we can conceive of someone doing something that would make him deserve to have polluted air. For example, if some morally responsible agent were to intentionally or negligently burn too much of a polluting fuel, then that agent might well deserve to have polluted air. (Free will skeptics hold that we are not actually morally responsible, but they can allow that moral responsibility is conceivable, and thus that action-based desert of polluted air is conceivable. ${ }^{8}$ ) Philosophers committed to moral universalism might suppose that all persons have a prima facie claim to fresh air not because they have acted in any particular way to become deserving of it, but simply because they are persons, but they might suppose that this desert is conditioned upon their not being morally responsible for intentionally or negligently acting in such a way as to pollute their air. But if this is true, it only implies that some desert claims which are in one sense personhoodbased are in another sense action-based. It does not imply that there are no non-trivial desert claims which are based solely on personhood. Said differently, Smilansky's example succeeds in 
showing that the residents' claims to deserve compensation because of their polluted air are not based on the sheer fact of personhood, but it does not succeed in showing that that there are not some other non-trivial desert claims which are based on the sheer fact of personhood.

Thus far in the paper, I have argued that there are some desert claims that are not based on actions, including our claims to deserve to be respected, to be given access to our rights, to be treated equally before the law, to be treated as innocent until proven guilty, and not to be used as a mere means to others' ends. I have also claimed that, for moral universalists, it is plausible to suppose that these desert claims are based on the sheer fact of personhood. In subsequent sections of the paper, I will assume that this supposition is true. Even with this supposition in place, more must be said to defend the thesis that these desert claims are not undermined by giving up the belief in moral responsibility. Two further claims which might make trouble for this thesis are, first, that personhood is a legitimate desert base only insofar as one is morally responsible for becoming a person, and second, that we cannot be persons at all unless we are morally responsible for our actions. The next two sections will present arguments against these two claims.

\section{$\underline{\text { 2. No One Could be Morally Responsible for Becoming a Person }}$}

Philosophers who think that the foundation of morality is a kind of autonomy which depends on free will may find it attractive to suppose that personhood is only a legitimate desert base insofar as one is morally responsible for becoming a person. (This may be true for philosophers influenced e.g. by existentialism, or by what might be termed existentialist readings

of Kant. ${ }^{9}$ ) If this view about the legitimacy of personhood as a desert base is true, it would imply that free will skepticism undermines personhood-based desert claims along with action-based 
desert claims. But it is not true, because no one could be morally responsible for becoming a person.

Two arguments for this claim will be presented. The first argument fits theories of moral responsibility which are based on the principle of alternative possibilities (PAP), according to which alternative possibilities are necessary for moral responsibility. The second (and shorter) argument fits theories which reject PAP.

First let us consider theories that accept PAP. There are different formulations of this principle. According to the original formulation, by Harry Frankfurt, "a person is morally responsible for what he has done only if he could have done otherwise" (Frankfurt 1969, 829). Some formulation or other of PAP is accepted by most incompatibilists, and by classical compatibilists (i.e. compatibilists who endorse the "conditional analysis" of "can" or one of its descendants). ${ }^{10}$ When one thinks about one's past actions, it is quite straightforwardly conceivable that one could have done otherwise. ${ }^{11}$ For example, if one robs a bank, and one's choice to do so was not based on coercion, insanity, or any other similarly limiting condition, it is conceivable that one could instead have chosen not to rob the bank. It is not, however, similarly conceivable that anyone ever had an alternative to becoming a person that he could have chosen instead. Even an ontology which posits disembodied souls who must decide to become incarnated before they can be born into the world does not posit non-persons contemplating the alternatives of becoming persons or not becoming persons-it posits disembodied persons contemplating the alternatives of becoming embodied persons or not becoming embodied persons. So having an alternative to becoming a person is inconceivable. This means that if alternative possibilities are necessary for moral responsibility, then no one could be morally responsible for becoming a person. 
It is conceivable that one could have an alternative to continuing to be a person, since that could depend on how one acts after deliberating about Hamlet's question. So it is conceivable that, by continuing to be a person when one has an alternative to continuing to be a person, one could become morally responsible for being a person. ${ }^{12}$ But one can only continue to be a person once one is a person. Since one's personhood is a desert base as soon as one is a person, not only after one has continued to be a person, the legitimacy of personhood as a desert base cannot depend upon becoming morally responsible for being a person.

The general line of argument defended here does not depend upon any particular formulation of PAP, though the details will vary with the formulation. For example, on Peter van Inwagen's formulation, PAP is the principle that a person is morally responsible for making it the case that $\mathrm{P}$ only if he could have rendered P false (van Inwagen, 1983). In van Inwagen's terms, the main claim defended in this section is that no one could have rendered $\mathrm{P}$ false where $\mathrm{P}$ is the proposition that one became a person. One could have rendered false the proposition that one is a person at time $t$ if one had the power at some time prior to $t$ to voluntarily cease to be a person. But only a person could have the power to voluntarily cease to be a person. So one could only have the power to voluntarily cease to be a person once one is already a person. This means that no one could have rendered false the proposition that one is a person at time $t$ where $t$ is the first instant of one's personhood, that is, the instant at which one became a person, and personhood is a legitimate desert base as soon as one becomes a person.

Now let us consider non-PAP theories. Harry Frankfurt rejected PAP in an influential paper (Frankfurt 1969) and a significant number of philosophers currently writing on free will, both compatibilists and incompatibilists, follow him in this. ${ }^{13}$ But on Frankfurt's theory, it is true 
by definition that no one can be morally responsible for becoming a person. A discussion of Frankfurt's theory may allow us to draw some lessons for non-PAP theories more generally.

Frankfurt must accept that no one can be morally responsible for becoming a person because of how he defines personhood and moral responsibility. According to Frankfurt, to be a person, one must have a second-order volition. A second-order desire is a desire about a firstorder desire, and a first-order desire is a desire about something other than a desire; a secondorder volition is the kind of second-order desire one has when one wants a particular first-order desire to be one's will, i.e. when one wants a particular first-order desire to effectively motivate one to act. When an agent forms a second-order volition, he "identifies himself" with one of his first-order desires (Frankfurt 1971, 13). Frankfurt refers to agents who have no second-order volitions as "wantons". Wantons may have conflicting first-order desires, but they let the conflict play out without ever desiring that any particular first-order desire be the one that effectively motivates them to act. They may even sometimes reflect on their desires, but they never form second-order volitions. Frankfurt holds that free will is the ability to make one's will conform to one's second-order volitions, and that to be morally responsible for one's actions, one must act in accordance with one's second-order volitions. Since he holds that having a secondorder volition makes one a person, he must accept that one cannot be morally responsible for anything at all unless one already is a person.

There is reason to think that other philosophers who follow Frankfurt in rejecting PAP must also follow Frankfurt in holding that non-persons are not morally responsible. Any theory of moral responsibility which rejects PAP must hold that agents are morally responsible because they have some special psychological constitution in the actual causal series. (Depending on the theory at issue, this might be a psychological constitution which makes the agent responsive to 
reasons, or makes him the source of his actions, or gives him a particular sort of control over his actions, etc.) But any agent with a psychological constitution that could be thought sufficient for moral responsibility would be such that personhood-based desert claims could be made either by him or on his behalf, and this is sufficient for being a person. If this is right, then anyone who rejects the alternative possibility condition must accept that morally responsible agents are already persons, and therefore that no one could be morally responsible for becoming a person.

Now let us consider an objection. Based on Frankfurt's account of personhood, it might be argued that one could have an alternative to becoming a person. ${ }^{14}$ In other words, Frankfurt's account of personhood might be grafted onto a PAP theory, thereby producing a hybrid theory according to which one could be morally responsible for becoming a person.

This issue arises because Frankfurt's distinction between wantons and persons seems to make it possible to conceive of having an alternative to becoming a person. We seem to be able to imagine a wanton reflecting on some conflicting first-order desires and deliberating about whether to identify himself with one or the other, i.e. deliberating about whether or not to form a second-order volition. If a wanton forms a second-order volition as the result of such deliberation, and thereby becomes a person, it seems to be conceivable that the wanton had an alternative to becoming a person.

We can reject this line of argument, however, if we hold that Frankfurt sets too high a standard for personhood, and we hold that wantons are persons too. This claim is supported by the idea of personhood as a desert base. It is sufficient for being a person that one can make personhood-based desert claims, and wantons can make personhood-based desert claims. Wantons deserve to be given access to their rights, to be treated equally before the law, to be treated as innocent until proven guilty, and not to be used as a mere means to others' ends. And 
even if wantons are not fully-fledged rational agents, they deserve the special kind of respect that goes with recognizing someone as a person. So wantons cannot be supposed to lack personhood.

The upshot of this section might be stated as follows: moral responsibility implies

personhood, in such a way that no one could be morally responsible for anything unless one was already a person. This had to be established to block the claim that one's personhood might be a legitimate desert base only insofar as one was morally responsible for becoming a person. That claim had to be blocked because it would force us to conclude that giving up the belief in moral responsibility would undermine personhood-based desert along with action-based desert. But we might also be forced to that conclusion if it were the case that personhood implies moral responsibility. The project of the next section will be to argue against that claim.

\section{Personhood Does Not Imply Moral Responsibility}

It might be argued that personhood implies moral responsibility. In other words, it might be argued that the characteristics which someone must have to be a person are also sufficient to make her morally responsible for her actions. If this is right, then giving up the belief in moral responsibility would require us to give up the belief in personhood, and personhood could not serve as a desert base in our ethical theories. To block this implication, it will be argued in this section that personhood does not imply moral responsibility.

Here is a quick argument for this claim which begins from the discussion of wantons' personhood in the previous section (where it was argued, contra Frankfurt, that wantons are persons). It is sufficient for being a person that one can make personhood-based desert claims, and wantons can make personhood-based desert claims. But wantons are not morally responsible for their actions (as Frankfurt correctly holds, though perhaps not for the right reasons). ${ }^{15}$ Therefore personhood does not imply moral responsibility. 
This is a sound argument, but it does not shed as much light as might be desired on why philosophers might worry that personhood implies moral responsibility. Two ways of arguing that personhood implies moral responsibility will be discussed below: first, that free will is the ability to do things for reasons, and this ability is a necessary attribute of persons; and second, that persons must be accessible to the reactive attitudes. It will be argued that neither of these arguments goes through.

No attempt will be made here to give a detailed account of necessary and sufficient conditions for personhood. But it is probably safe to say that to be a person, one must have the ability to do things for reasons. Some may hold that this ability is sufficient for free will. ${ }^{16}$ If this is correct, then one has free will, and thereby satisfies the control condition of moral responsibility, just by virtue of being a person. This would mean that if no one has free will, then there are no persons. So free will skeptics who wish to preserve a place for personhood in their ethical theories must deny that the ability to do things for reasons is sufficient for free will.

To deny this, we must distinguish the kind of control involved in doing things for reasons from the kind of control that satisfies the control condition of moral responsibility. Beings that can do things for reasons stand in a special relationship to the events which are their actions, a relationship which is profoundly different from the relationship between beings that cannot do things for reasons and the events which are merely their effects. It is certainly correct to understand this special relationship as involving a kind of control. But this kind of control is not enough, all on its own, to make someone morally responsible for their actions. Wantons can once again serve as an example in support of this view. Wantons' first-order desires ground reasons for action, so when they act in accordance with their first-order desires, they do things 
for reasons. But they do not have free will. ${ }^{17}$ Therefore it is possible to have the ability to do things for reasons without having free will.

Free will skeptics must of course hold that even when persons act in accordance with second-order volitions they do not have free will. Free will skeptics hold that we do not have adequate reasons for believing that anyone has free will in the actual world, no matter how sophisticated we suppose their volitional capacities to be. But if sophisticated volitional capacities are not necessary for personhood, then it is not necessary to argue for these more controversial claims to defend the claim that personhood does not imply moral responsibility. Since I have argued that the relatively simple volitional capacities of wantons are sufficient for personhood, I will not argue for these more controversial claims here.

Now let us turn to the argument that persons must be accessible to the reactive attitudes. John Martin Fischer makes this argument. If he is right, then giving up the belief that human beings are morally responsible would also require us to give up the belief that human beings are persons. According to Fischer,

Persons are appropriate candidates for such attitudes as love, respect, gratitude, resentment, indignation, and hatred. In his path-breaking essay, Peter Strawson dubbed these the "reactive attitudes."...The reactive attitudes are essential ingredients of our lives as we lead them. Imagine, if you will, a world without love, gratitude, indignation, and resentment. It would be a colorless and cold world, and certainly radically different from ours. Further, the relationships and practices built upon the reactive attitudes are central features of our lives. Friendship, for example, seems to be intimately bound up with the network of reactive attitudes....I shall call rational (or appropriate) accessibility to the reactive 
attitudes and the attendant practices of moral reward and punishment, "moral responsibility". (Fischer 1995, 2)

Fischer goes on to claim that such "appropriate accessibility" to the Strawsonian reactive attitudes is one of the "key normative ingredients in the notion of personhood" (Fischer 1995, 23). The core of Fischer's argument seems to be the following: for someone to be morally responsible is just for it to be appropriate to take up reactive attitudes toward them, and moral responsibility is part of the concept of a person because the human beings populating the "cold world" which would be left behind if no one ever took up the reactive attitudes toward anyone else could not truly be said to be persons at all.

Free will skeptics should probably concede that some of the attitudes Fischer lists (e.g. resentment and gratitude) are essentially reactive, i.e. that that they are intrinsically bound up with holding people morally responsible. It is hard to see any place for these attitudes in free will skeptics' ethical theories. But love is not essentially reactive, and neither is respect. So ridding ourselves of the reactive attitudes would change relationships between human beings, but it would not leave us in a depersonalized "cold world".

This point can be illustrated with respect to two kinds of love and respect. There is a particularistic kind of love which is explained by characteristics of the person loved, and a nonparticularistic kind of love which is based on the sheer fact of personhood. The same distinction exists for respect. Particularistic love and respect can be conceived to be reactive, but need not be. Love and respect which are based on the sheer fact of personhood cannot be conceived to be reactive. $^{18}$

First let us consider particularistic love and respect. Particularistic love is the kind of love which "attaches" us to particular other persons in relationships of friendship or romantic 
love. That is, the fact that one is attached to one person but not another in a relationship of friendship or romantic love is typically explained by the fact that the person to whom one is attached has particular characteristics which the other does not have. In some cases, it is unproblematic to conceive of such love as reactive, i.e. as a deserved response to characteristics persons are morally responsible for possessing. Suppose Linda successfully acts in ways designed to cultivate or maintain virtues such as loyalty and dedication to the truth, and Doug loves Linda because of these virtues. If Doug supposes that Linda is morally responsible for these actions, then he can take his love to be a response to Linda which she can claim to deserve. But in many cases this way of conceiving particularistic love is problematic. Suppose Hal is also loyal and dedicated to the truth, but he has done nothing to cultivate or maintain these virtues. He has always been this way - it is just (as the saying has it) his nature. Bud may befriend Hal for these virtues even if Bud knows (1) that Hal has done nothing to cultivate or maintain them, and Bud believes (2) that there is no reason to suppose anyone to be morally responsible for possessing virtues he has done nothing to cultivate or maintain, and he concludes (3) that his friendship for Hal is not a response which Hal can claim to deserve. ${ }^{19}$ It is by no means obvious that Bud's relationship with Hal has any less depth or significance, or is in any other way less "personal", than Doug's relationship with Linda.

A similar point can be made with respect to particularistic respect, since it is also possible to respect persons for virtues which they have done nothing to cultivate or maintain. Tom might respect Tim for being courageous in this way despite believing that Tim deserved no praise for it. He might point out Tim's courage to others, he might invest great energy in explaining why Tim's courage was valuable, and he might even celebrate Tim's courage. None of this implies praising Tim for his courage. 
Since it is possible to have particularistic love and respect for persons because of characteristics for which they are not morally responsible, neither love nor respect is essentially reactive. This means that the view of free will skeptics that persons are never morally responsible for their characteristics does not prevent free will skeptics from accommodating particularistic love and respect. Free will skeptics hold that even when persons (like Linda in the recent example) $d o$ act in special ways in order to cultivate or maintain their virtues, they are not actually morally responsible for those actions. It follows that even in such cases, particularistic love and respect are not actually responses to persons which they can claim to deserve. But the fact that love and respect are not essentially reactive means that we can accept this point yet continue to have particularistic love and respect for people in these cases.

A point which has thus far been implicit in this discussion, but which may be useful to consider on its own, is that persons' particular characteristics can be objects of moral evaluation even if they cannot be desert bases. Free will skeptics cannot praise or blame persons for virtues or vices. But this does not imply that free will skeptics must refrain from morally evaluating persons. For example, recognizing persons' virtues and encouraging the maintenance of those virtues does not entail praise, and recognizing persons' vices and encouraging the elimination of those vices does not entail blame. ${ }^{20}$

It may be objected that it is impossible to ascribe virtues and vices to persons without praising and blaming them. But to hold that this is possible is just to distinguish between persons' possession of character traits, on the one hand, and persons being morally responsible for possessing those character traits, on the other. Perhaps the most intuitive starting point for grasping this distinction is to consider cases where persons' characters are warped by childhood abuse. A person may be caused to become cruel by childhood abuse, and in such cases it is 
clearly mistaken to blame the person for his cruelty. ${ }^{21}$ But we can quite consistently note this vice, and caution others about it, and exhort this person to become kinder, perhaps through therapy. Free will skeptics hold that all virtues and vices have etiologies which make all praise and blame similarly misplaced, but they can nonetheless recognize virtues and vices as objects of moral evaluation.

Now let us consider non-particularistic love and respect. Non-particularistic love and respect cannot be conceived to be reactive in the Strawsonian sense because they are based on the sheer fact of personhood. That is, these attitudes are not grounded on persons' characteristics, so there is nothing for them to be reactions to. An example of non-particularistic love is the care we have for persons in general when we worry (e.g.) about how environmental pollution will affect the future of humanity. It may be that we can make personhood-based claims to deserve this sort of love. Free will skeptics could readily accommodate such desert claims.

To have non-particularistic respect for persons is to respect persons' personhoodbased desert claims. We make implicit personhood-based claims to deserve this sort of respect whenever we make personhood-based claims to deserve anything at all, but we can also make explicit claims to deserve it. ${ }^{22}$ (This sort of respect includes a great deal of what Kant has in mind in his idea of regarding others as ends-in-themselves. ${ }^{23}$ For example, free will skeptics can follow Kant in making respect for our right to independently set our own ends a central moral principle. So long as we understand what we are independent from as the undue influence of others, rather than the causal nexus constituting the world, this view is entirely compatible with free will skepticism.) 
It may be objected that we must act if we are to respect, or fail to respect, personhoodbased desert claims, so if actions are not legitimate desert bases, then no one deserves to be praised or blamed for respecting, or failing to respect, personhood-based desert claims. For example, a person deserves to have his vote count equally just because he is a person. But a vote counter's refusal to count the person's vote is an action of the vote counter, and if actions are not legitimate desert bases, the vote counter cannot deserve blame. Here too, however, free will skeptics can accept this point without giving up on moral evaluation. It is wrong not to respect legitimate desert claims, and free will skeptics can point this out to the vote counter and exhort him to become more virtuous without blaming him for his vice.

Since neither love nor respect is essentially reactive, Fischer is wrong to claim that interpersonal relationships would become cold and depersonalized without the reactive attitudes. Since this claim is the core of his argument that personhood entails moral responsibility, his argument does not go through.

By this point in the paper, I have argued in some detail that personhood remains a legitimate desert base in the absence of the belief in moral responsibility, even though actions do not remain legitimate desert bases. First, the distinction between personhood-based and actionbased desert was explained. Then, to block the objection that one's personhood might be a legitimate desert base only insofar as one was morally responsible for becoming a person, I argued that no one could be morally responsible for becoming a person. Next, to block the objection that one cannot be a person at all if one is not morally responsible, I argued that personhood does not imply moral responsibility.

Now let us turn to a different sort of question. Suppose we accept that personhood is the only legitimate desert base. What would it mean to organize a just society in this light? 


\section{Justice and Personhood as a Desert Base}

What would social justice amount to if we recognized personhood as a legitimate desert base, but not actions? All persons are identical with respect to the sheer fact of their personhood, so all persons will have identical personhood-based desert claims. But how is this to be interpreted? Does it mean, with respect to a given sandwich, that everyone deserves the sandwich? This approach would be difficult to implement. It might instead be supposed that everyone deserves an equal share of what society can distribute. But what about those who need more than others? Designing society in accordance with the Marxist motto "from each according to his ability, to each according to his need" might be an improvement. But it would saddle us with the problem of determining which needs are legitimate as well as a problem about which abilities, and what proportion of them, society can legitimately annex.

In order to set these problems to the side and thereby simplify our task, an approach based on Rawls' idea of the original position will be proposed. ${ }^{24}$ In this way, the problem of interpreting the equality of desert claims can be resolved procedurally, that is, through the procedure of original-position deliberation. The original position is an idealized standpoint in which the members of a society choose the basic principles that will govern their society. It is formed by drawing what Rawls calls a "veil of ignorance" between the people who make up a society and all their particular characteristics. In the original position, one cannot know whether one is among the best or worst off, what one's religion, ethnicity, or sex is, what patterns of action one exhibits (for example, whether one is industrious or lazy), and so on. So deliberators in the original position must choose principles to govern society without knowing where they will end up within society. Rawls holds that the veil of ignorance ensures that the principles chosen in the original position will be just, since one will not be able to choose principles that 
make any of one's particular characteristics advantageous. Further, since people are selfinterested and risk-averse in conditions of uncertainty, deliberators will worry most about ending up among the worst-off members of society, and they will therefore choose principles which make the lot of the worst-off members of society the best it can be.

Now, a claim will be made which is not part of Rawls' own view, but which is not alien to the spirit of his view: the deliberators in the original position can be represented as choosing principles in light of how they deserve to be treated. Since the "veil of ignorance" screens out knowledge of all particular characteristics of persons, particular characteristics cannot be invoked as desert-bases. The only epistemically possible desert base in the original position is the sheer fact that the deliberators are persons. ${ }^{25}$ This means that in the original position, deliberators choose principles in the light of only those desert-claims that can be based on the sheer fact of personhood. ${ }^{26}$

Rawls himself distinguishes between what he calls "moral desert", on the one hand, and "entitlement", on the other. He rejects moral desert, and claims that only entitlement plays a role in his theory. For this reason, he would describe claims that people can make based on the fact of their personhood as entitlement claims. This is largely a terminological difference, but it is not an entirely trivial one. Rawls' way of speaking can be misleading, because persons are sometimes said to be entitled to things which it is morally arbitrary for them to have. Suppose that, in a fit of largesse, Barrington signs the deed to one of his mansions over to Oxley, because he pities Oxley for only having two mansions when he has eight. There is no sense in which Oxley deserves the additional mansion, because Barrington's gift was a response to his own morally arbitrary feelings, not a response to a morally relevant property of Oxley. But (at least according to some ethical theories) Oxley might nonetheless be said to be entitled to the 
mansion. ${ }^{27}$ To treat persons as equal before the law just because they are persons, on the other hand, is to respond to a morally relevant property of theirs. So to lump personhood-based claims and claims like Oxley's together as two kinds of entitlement is to blur an important distinction. For this reason, it is useful to use the term "desert" rather than "entitlement" for what we can claim based on our personhood.

Despite this terminological difference, Rawls' overall position on desert is similar, in central respects, to the one presented here. Rawls designs the original position to screen out knowledge of all particular characteristics of persons because he thinks they are morally irrelevant to choosing the basic principles of society. As he argues in section 17 of $A$ Theory of Justice, these characteristics are morally irrelevant because no one deserves to have them, so no one deserves a social arrangement in which he is advantaged or disadvantaged by them. When Rawls rejects moral desert, what he means to reject is just this conferring of advantage based on the particular characteristics screened out by the veil of ignorance. In fact, at one point Rawls describes entitlement as a different "sense of desert" (1999, 88-89).

Nonetheless, some of what Rawls says about the "sense of desert" he endorses may initially seem perplexing from the perspective of the present paper. According to Rawls, given a just system of cooperation as a framework of public rules, and the expectations set up by it, those who...have done what the system announces that it will reward are entitled to have their expectations met. In this sense the more fortunate have title to their better situation; their claims are legitimate expectations established by social institutions...But this sense of desert is that of entitlement. It presupposes the existence of an ongoing cooperative scheme[.]

$(1999,88-89)$ 
Rawls' claim here is that persons can come to be entitled to advantages if they get them by following just rules, that is, rules based on principles that would be chosen in the original position. But following rules is a matter of acting in particular ways, so this "sense of desert" must somehow involve reference to actions. On initial inspection, there seems to be a tension between this idea and the theory being developed here, given its goal of recognizing personhood, but not action, as a legitimate desert base. But in fact, the present theory requires reference to actions. Though the principles chosen in the original position are personhood-based, some of these principles cannot be implemented in society without reference to actions. In such cases, implementing personhood-based principles in society produces personhood-based desert claims which function as legitimate analogues of action-based desert claims.

One principle that requires reference to actions for its implementation is what Rawls calls the "difference principle". This is the principle that economic inequalities are just only if they improve the conditions of the worst-off members of society. This implies that it is just for the industrious to reap advantages from their industry only if the economic dynamics this produces improve the lot of the worst off. There is of course a widely held belief among economists that allowing the industrious to benefit (to some degree) from their industry produces an incentive to be industrious and increases overall productivity, and that increasing overall productivity improves the lot of the worst-off. ${ }^{28}$ Insofar as this is true, it is just to allow the industrious to reap advantages from their industry. Since the difference principle would be chosen in the original position, persons deserve to be treated in accordance with it, and for this reason, the industrious can make personhood-based claims to deserve the fruits of their industry.

This claim must be carefully framed. The only reason why anyone deserves the fruits of industry is that the difference principle would be chosen in the original position, where the sheer 
fact of personhood is the only epistemically possible desert base. It is not possible to determine who deserves the fruits of industry by reference to the sheer fact of personhood, since all persons are identical with respect to this fact. It is only possible to determine who deserves the fruits of industry by reference to the industrious actions that are their cause. It must be emphasized that the sole reason why the industrious deserve anything on this theory is that if persons other than the persons whose actions produce the fruits of industry were to held deserve them, then there would be no incentive to be industrious, and the hypothesized increase in overall productivity and improvement of the conditions of the worst-off could not occur. The actions themselves are not desert bases. Instead, they are merely necessary reference-points for the implementation of personhood-based principles.

It may be objected that incentives can play no role in a free will skeptic's ethical theory. That is, it may be thought that if an industrious person has no free will, then he cannot help being industrious, so the presence of an incentive to be industrious can do nothing to explain his industry. But this is a mistake. The presence of an incentive to be industrious may help explain why industrious people cannot help being industrious (as it were). Suppose an industrious worker has no free will because he inhabits a deterministic world. The point is that an incentive to be industrious can be part of the deterministic causal explanation of why he is industrious. If the incentive is part of the explanation, then this implies that in an alternative possible deterministic world which contained a psychologically indistinguishable worker, and which differed from the actual world only in that it lacked the incentive, that worker would not be as industrious as the worker is in the actual world.

It must be emphasized that the truth of personhood-based desert claims which refer to actions, i.e. personhood-based analogues of action-based desert claims such as the industrious 
worker's claim to deserve the fruits of industry, is contingent in a way that the truth of personhood-based desert claims which make no reference to actions is not. The industrious can only make personhood-based claims to deserve the fruits of their industry insofar as it is true that the practice of differentially rewarding persons in light of their efforts creates economic dynamics which can be made to improve the lot of the worst-off. We can imagine societies for which this claim is not true, for example, societies where productivity is not affected by the presence or absence of such an incentive. It is of course not entirely within the precinct of philosophers to speculate about its truth for actual societies. But at the risk of armchair anthropology, it seems plausible to think that it is probably true for actual societies.

\section{$\underline{\text { Conclusion }}$}

This concludes the account to be given here of the role which can be played by personhood as a desert base in free will skeptics' ethical theories. In the first section, I argued that there are non-trivial desert claims which are not action-based, and which we can plausibly suppose to be based on the sheer fact of personhood. I also explained a contrast between my approach and Saul Smilansky's approach. In the second section, I argued that no one could be morally responsible for becoming a person. I presented arguments to fit both PAP and non-PAP theories, and I discussed a hybrid theory produced by grafting Frankfurt's account of personhood onto a PAP theory. In the third section, I argued that personhood does not imply moral responsibility. The main discussion focused on Fischer's Strawsonian rationale for the view that personhood implies moral responsibility, as well as examples of non-reactive love and respect which demonstrate flaws in that rationale. In the fourth section, I drew on some Rawlsian ideas to argue that there are legitimate personhood-based analogues of action-based desert claims in 
some cases. The conclusion I draw is that, while free will skepticism would require substantial revisions of our beliefs about desert, the revisions required would not be as dramatic as is often assumed.

\section{$\underline{\text { Notes }}$}

Acknowledgements: This research was supported (in part) by funds from a Summer Stipend from the Research Center for the Humanities and Social Sciences at William Paterson University. Earlier versions of this paper were presented in a colloquium at William Paterson University in 2005, at the 2006 Northwest Conference, and at the 2006 Eastern APA. Thanks to my colleagues at William Paterson, to Robert Johnson (who commented at the APA), and to Noa Latham (who commented at the Northwest Conference). Thanks also to Saul Smilansky, Joseph Keim Campbell, Kadri Vihvelin, Alex Rajczi, and the editor and anonymous reviewers at the Canadian Journal of Philosophy.

${ }^{1}$ Examples of this view can be found in Rachels $(1978,157)$ and Sadurski $(1985,131)$. Pereboom $(2001,160)$ also seems to hold this view: he says giving up the belief that human beings are morally responsible requires us to give up the belief in "basic" desert. Smilansky (1996, 2000, 2005) holds a closely related position (to be discussed below), i.e. that giving up the belief that human beings are morally responsible implies giving up all our morally significant beliefs about desert.

${ }^{2}$ This claim is in contrast with the views in P.F. Strawson (1963), Fischer (1995), and Smilansky (2000, 2005), all of whom hold that rejecting the belief in moral responsibility would erode respect for persons.

${ }^{3}$ Feinberg himself does not discuss personhood as a desert base. 
${ }^{4}$ That is, persons are often praised and blamed for their character traits, but as David Miller notes, there is a historical trend toward limiting such praise and blame to character traits agents have acquired or preserved voluntarily (Miller 1976). It seems right to recognize this trend as moral progress.

${ }^{5}$ Fred Feldman discusses this point, but not in the context of free will skepticism. (Feldman 1995).

${ }^{6}$ Even if Smilansky is correct, the kind of action-based desert claims he claims we must make to explain why persons deserve compensation for falling below the baseline do not conflict with free will skepticism. That is, on Smilansky's account, to claim that we deserve compensation for falling below the baseline, we need only claim that we are not morally responsible for actions that would make us deserve to fall below it. (Feldman 1996 also points this out, but not in the context of free will skepticism.) Clearly, free will skepticism is compatible with the claim that we are not morally responsible for any such actions. Smilansky acknowledges this at one point, when he notes that his account "allows us to speak of desert even if we take a hard determinist position"(2000, 44). He goes on, however, to claim that desert is "only morally central" because of its connection to free will and moral responsibility. This seems to be mistaken in view of the point just considered. But irrespective of how things stand with this issue, it is important to make the broader point that that there are non-trivial personhood-based desert claims which are entirely independent of action-based desert claims, and that is the aim of the discussion in the main text above.

${ }^{7}$ Thanks to the Editor for suggesting this point.

${ }^{8}$ Derk Pereboom also holds this view. He argues that libertarian agent causation is essential to moral responsibility, and that libertarian agent causation is not incoherent, but that given the sort 
of indeterminism that is most likely to be true, the libertarian agent causation theory is false (see Pereboom 2001, Chapters 2 and 3, and 2006).

${ }^{9}$ Korsgaard's appeals to "self-creation" might lead one to entertain such a view (though they do not imply it). (See e.g. Korsgaard 1996.)

${ }^{10}$ Incompatibilists who endorse PAP include Carl Ginet (1996), David Widerker (1995), Robert Kane and (1996). The compatibilist "conditional analysis" can be traced back at least as far as Hume's An Enquiry Concerning Human Understanding (Hume 1975, Section 8, Part 1). G.E. Moore was another influential advocate of the conditional analysis (see Moore 1911, Ch. 6) and is largely responsible for its prominence during the heyday of analytic philosophy. Contemporary compatibilists have mostly rejected the conditional analysis, but accounts of free will descended from it remain influential (e.g. Campbell 1997 and 2005; Vihvelin 2004).

${ }^{11}$ Free will skeptics need not deny that this is conceivable; they need only deny that we have adequate reasons for believing it to be true.

${ }^{12}$ Having an alternative to something can only make one morally responsible for that thing if it is under one's power to act on that alternative. Even if we suppose that all human agents have free will with respect to some of their actions, it cannot be supposed that all agents have the power to act on a particular kind of alternative just because some agents do. To have the power to cease to be a person, one would have to be able to commit suicide, or to become a vegetable (perhaps by voluntarily submitting to a lobotomy), or to do something else equivalent. (It is not sufficient for having the power to cease to be a person for it to be the case that it is possible for one to die of disease, old age, etc., since such deaths are not under one's control in the relevant way.) Many people who consider suicide find that they cannot bring themselves to do it, and in such cases it seems wrong to suppose that they have the power to commit suicide. If such agents do not have 
the power to act on any alternative to continuing to be persons, then continuing to be persons could not make them morally responsible for being persons. But even if we suppose that all agents can become morally responsible for being persons by continuing to be persons, the fact that no one can be morally responsible for becoming a person implies that for at least the initial moment of one's personhood, one cannot be morally responsible for being a person.

${ }^{13}$ John Martin Fischer is a compatibilist who rejects PAP (see e.g. Fischer 1995). Derk Pereboom is a "causal history incompatibilist": he holds that what is needed for moral responsibility is not alternative possibilities, but rather a certain kind of control over the causal history that led up to the event for which one is to be morally responsible, a kind of control which would be ruled out by determinism. (Pereboom 2001, 2-6).

${ }^{14}$ Thanks to Kadri Vihvelin for suggesting that I discuss Frankfurt's account of personhood. ${ }^{15}$ In my view, wantons might be morally responsible if their actions satisfy PAP, but we do not have adequate reasons to believe that anyone's actions ever satisfy PAP in the actual world. Also see note 16.

${ }^{16}$ Kadri Vihvelin holds a view along these lines: she writes that "to have free will is to be capable of acting for reasons which are also causes" (1994, 119). Elsewhere, however, she suggests that this ability may only be a necessary condition for free will, stating that "free will is or includes the ability to make choices on the basis of reasons" $(2004,427)$. (It should be noted that Vihvelin makes some points which could be used to argue that wantons have free will, though she does not argue for this particular claim (1994, 131-141). But the argument would only work if wantons' actions satisfy PAP, and on my view they do not, at least not in the actual world. Also see note 15.)

${ }^{17}$ See notes 15 and 16. 
${ }^{18}$ Related distinctions are made by Slote (2001) and Darwall (1977). Slote distinguishes particularistic and generalized caring, and Darwall distinguishes appraisal respect and recognition respect.

${ }^{19}$ It is by no means obvious that the fact that Doug's love for Linda involves the notion of desert makes that love deeper, or more morally significant, than Bud's friendship for Hal. Even apart from free will skepticism, explanations of particularistic love in terms of desert ring false. To insist that particularistic love must be understood as a deserved response is to artificially impose upon it a concept which belongs in a different domain of ethics, i.e. the domain of justice.

${ }^{20}$ Michael Slote also discusses this point (Slote 1990).

${ }^{21}$ Slote offers a similar example (Slote 1990, 377).

${ }^{22}$ This is closely related to what Stephen Darwall calls "recognition respect" (Darwall 1977, 38).

${ }^{23}$ Kant, like Fischer, holds that personhood implies moral responsibility. The structure of his argument for this claim is a matter of controversy, and no interpretation of it will be attempted here. But it is nonetheless clear that significant elements of Kant's conception of personhood can be accommodated by free will skeptics. Also see Pereboom $(2001,151)$ on this topic. ${ }^{24}$ Erin Kelly also takes a broadly Rawlsian approach to desert in the context of skepticism about free will, but her concerns are different (Kelly 2002).

${ }^{25}$ It may be objected that original-position deliberators could in fact choose principles according to which actions are desert bases, despite their ignorance of how they themselves will act. But this is only possible if we reject Rawls' assumption of risk-averseness. If the assumption of riskaverseness is challenged, then the fallback position used by Rawls is also available to the account 
of justice advanced here. That is, deliberators must not endorse desert-bases which can vary from person to person because it would not be fair.

${ }^{26}$ Michael Sandel criticizes the thinness of the conception of personhood which remains after the veil of ignorance screens out all the particular characteristics of persons. But it is only because of this thinness that the conception of the person in the original position can model the sheer fact of personhood as a desert base (Sandel 1998, 20-25).

27 This sort of morally arbitrary entitlement plays a major role in Nozick's account of justice. Nozick also holds, contra Rawls, that "Whether or not people's natural assets are arbitrary from a moral point of view, they are entitled to them, and to what flows from them." (Nozick 1974, 225226).

${ }^{28}$ Redistributive taxation is another way that the economic advantages of the industrious can be made to improve the lot of the worst-off.

\section{$\underline{\text { References }}$}

Campbell, J.K. 1997. "A Compatibilist Theory of Alternative Possibilities." Philosophical Studies 88 (1997): 319-330.

---. 2005. "Compatibilist Alternatives." Canadian Journal of Philosophy 25 (2005): 387-406.

Darwall, S. 1977. "Two Kinds of Respect." Ethics 88.1 (1977): 36-49.

Feinberg, J. 1963. "Justice and Personal Desert." In Nomos VI: Justice, ed. C.J. Friedrich and J.W. Chapman. New York: Atherton Press.

Feldman, F. 1996. "Responsibility as a Condition for Desert." Mind 105.417 (1996): 165-168.

---. 1995. "Desert: Reconsideration of Some Received Wisdom." Mind 104.413 (1995): 63-77. 
Fischer, J.M. 1995. The Metaphysics of Free Will (Aristotelian Society Series v. 14). Malden, MA: Blackwell Press.

Frankfurt, H. 1969. "Alternate Possibilities and Moral Responsibility." Journal of Philosophy 66 (1969): 829-839.

---. 1971. "Freedom of the Will and the Concept of a Person", Journal of Philosophy 68.

Ginet, C. 1996. "In Defense of the Principle of Alternative Possibilities: Why I Don’t Find Frankfurt's Argument Convincing." Philosophical Perspectives 10 (1996): 403-417.

Hume, D. 1975. Enquiries Concerning Human Understanding and Concerning the Principles of Morals, ed. L.A. Selby-Bigge. New York: Oxford.

Kane, R. 1996. The Significance of Free Will. New York: Oxford University Press.

Kelly, E. 2002. "Doing Without Desert." Pacific Philosophical Quarterly 83 (2002): 180-205.

Korsgaard, C. 1996. The Sources of Normativity. Cambridge, MA: Cambridge University Press.

Lewis, D. 1981. "Are We Free to Break the Laws?" Theoria 47 (1981): 113-121.

Miller, D. 1976. Social Justice. Oxford: Clarendon Press.

Moore, G.E. 1911. Ethics. Oxford: Oxford University Press.

Nozick, Robert. 1977. Anarchy, State, and Utopia. New York: Basic Books.

Pereboom, D. 2001. Living Without Free Will. New York: Cambridge University Press.

---. "Is Our Conception of Agent-Causation Coherent?" Philosophical Topics 32 (2006): 275286.

Rachels, J. 1978. "What People Deserve." In Justice and Economic Distribution, ed. J. Arthur and W.H. Shaw. Englewood Cliffs, NJ: Prentice-Hall.

Rawls, J. 1999. A Theory of Justice, Revised Edition. Cambridge, MA: Harvard Belknap. 
Sadurski, W. 1985. Giving Desert Its Due: Social Justice and Legal Theory. Dordrecht: D. Reidel.

Sandel, M. 1998. Liberalism and the Limits of Justice, 2nd Edition, New York: Cambridge University Press.

Slote, M. 2001. Morals from Motives. New York: Oxford University Press.

---. 1990. "Ethics Without Free Will." Social Theory and Practice 16.3 (1990): 369-383.

Smilansky, S. 1996. "Responsibility and Desert: Defending the Connection." Mind 105.417 (1996): 157-63.

---. 2000. Free Will and Illusion. Oxford: Oxford University Press.

---. 2005. "Free Will and Respect for Persons." Midwest Studies in Philosophy 29 (2005): 248261.

Strawson, P.F. 1963. "Freedom and Resentment." Proceedings of the British Academy 48 (1963): 1-25.

van Inwagen, Peter. 1983. An Essay on Free Will. Oxford: Clarendon Press.

Vihvelin, K. 1994. "Stop Me Before I Kill Again." Philosophical Studies 75 (1994): 115-148.

---. 2004. "Free Will Demystified: A Dispositional Account." Philosophical Topics 32 (2004): 427-450.

Widerker, D. 1995. "Libertarianism and Frankfurt's Attack on the Principle of Alternative Possibilities." The Philosophical Review 104 (1995): 247-261. 
